\title{
Effects of replacing grain feed with rumen-protected fat on feedlot performance, ruminal parameters and blood metabolites in growing Merino lambs' diets during the hot season
}

\author{
Hıdır GÜMÜŞŞ,a, ${ }^{1, \text { Fatma KARAKAŞ OĞUZ }}{ }^{1, b}$, Mustafa Numan OĞUZ ${ }^{1, c}$, \\ Kadir Emre BUĞDAYCI ${ }^{1, d}$, Hüseyin DAĞLI ${ }^{1, e}$ \\ ${ }^{1}$ Burdur Mehmet Akif Ersoy University, Faculty of Veterinary Medicine, Department of Animal Nutrition and Nutritional Disease, \\ Burdur, TURKEY

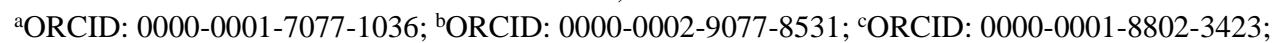 \\ dORCID: 0000-0002-1715-6904; ' ORCID: 0000-0002-7215-2340
}

Corresponding author: hdrgumus@gmail.com, hgumus@mehmetakif.edu.tr

Received date: 08.01.2021 - Accepted date: 11.05.2021

\begin{abstract}
In this study, the effects of rumen-protected fat (RPF) were evaluated as an energy source for partial replacement of grain feed in the diets of Merino male lambs during the hot season. Fourteen six months old Merino male lambs weighing average of $29.59 \mathrm{~kg}$ were randomly allocated into two groups: control diet (CON) and diets supplemented with $30 \mathrm{~g} / \mathrm{kg}$ RPF. Live weight (LW), dry matter intake (DMI) and average daily gain (ADG) were recorded, and the feed conversion ratio (FCR) was then calculated. The ruminal $\mathrm{pH}$, the ruminal ammonia nitrogen concentrations $\left(\mathrm{NH}_{3}-\mathrm{N}\right)$ value, the molar proportion of volatile fatty acid (VFA), blood serum as well as hematological parameters were determined and protozoa numbers were counted. While the live weight and daily gain of the lambs were not influenced by dietary treatments, DMI was increased with RPF supplementation. The ruminal pH, VFA and ruminal $\mathrm{NH}_{3}-\mathrm{N}$ concentrations were unchanged, but the protozoa numbers decreased significantly by $\mathrm{RPF}$ supplementation $(\mathrm{P}<0.05)$. RPF supplementation significantly affected some serum and hematological parameters in comparison to the control group. In conclusion, RPF may be added to concentrate mixture lamb feed at the level of $30 \mathrm{~g} / \mathrm{kg}$ to enhance the diet energy density without negatively changing the animal's performance.
\end{abstract}

Keywords: By-pass fat, fattening, male lambs, rumen parameters.

\section{Sıcak aylar boyunca Merinos ırkı kuzu rasyonlarına tane yem yerine ilave edilen rumenden korunmuş yăg ilavesinin besi performansı, rumen parametreleri ve kan metabolitleri üzerine etkileri}

Özet: Bu çalışmada, sıcak sezon boyunca Merinos ırkı erkek kuzu rasyonlarına enerji kaynağı olarak tane yem yerine rumende korunmuş yağ ilavesinin etkileri değerlendirilmiştir. Ortalama 29,59 kg canlı ağırlığında 6 aylık yaşta, 14 adet Merinos ırkı erkek kuzular rastgele kontrol grubu ve diyete $30 \mathrm{~g} / \mathrm{kg}$ rumende korunmuş yağ ilave edilen grup olarak ikiye ayrılmıştır. Canlı ağırlık, kuru madde tüketimi ve ortalama günlük canlı ağılık artışı kayıt altına alınmış ve yemden yararlanma oranı hesaplanmıştır. Rumen pH değeri belirlenmiş, rumen amonyak-azot konsantrasyonları analiz edilmiş, protozoalar sayılmış ve kan serum ile hematolojik değerler belirlenmiştir. Korunmuş yağ ilavesi deneme gruplarında kuzuların canlı ağırlık ve günlük canlı ağırlık artışı önemsiz olarak etkilenirken, kuru madde tüketimi artmıştır. Korunmuş yağ ilavesi ile rumen pH değeri, uçucu yağ asitleri ve rumen amonyak-azotu konsantrasyonları değişmezken, protozoa sayısı önemli derecede azalmıştır. Kontrol grubu ile karşılaştırıldığında korunmuş yağ ilavesi bazı serum ve hematolojik parametrelerini önemli derecede etkilemiştir. Sonuç olarak kuzu konsantre yemlerine $30 \mathrm{~g} / \mathrm{kg}$ korunmuş yağ hayvanın performansını negatif etkilemeksizin diyetin enerji değerini artırmak için rasyonlara ilave edilebilir.

Anahtar sözcükler: Besi performansı, korunmuş yağ, erkek kuzu, rumen parametreleri.

\section{Introduction}

Lambs fed on pasture have usually lower daily gain, and thus, they grow slower than those fed highconcentrate diets (9). However, in case of an excessive amount of available carbohydrates in the diet, rumination time and saliva production decrease, which further decrease ruminal $\mathrm{pH}$ (16) and increase risk for acidosis $(22,27)$. Ruminal acidosis leads to economic losses through declining $(10,27)$ dry matter intake (DMI). In such cases, the ruminal $\mathrm{pH}(<5.8)$ decreases mainly due 
to an increased accumulation of volatile fatty acids (VFAs) in the rumen (13). The higher dissociation and accumulation of VFAs increase the release of lipopolysaccharides (LPS) because of the death of bacteria, which adversely affect the animal's productivity and performance (13). Due to the negative effects of higher levels of readily fermented carbohydrates in the diet on animal performance (37) the energy balance of a diet could easily be compensated (31) by inclusion of rumen protected fat (RPF) or unprotected fat as a replacement for grain feeds in the rations of lambs (30). Several studies have been carried out to determine the optimal nutrition to improve animal performance, including fat supplementation $(8,23,25)$. The use of unprotected fat by above $5 \%$ is proven to have some negative impacts on the microbial function of the rumen (30) such as decreased microbial activity of cellulolytic bacteria (7) resulting in decrease of the available nutrient digestibility (17) and rumen protozoal counts (8). However, RPF, also called "inert fat", passes the rumen directly and is digested in the abomasum and duodenum by enzymatic and chemical reactions (25) without causing any negative effects on the rumen's bacterial flora $(4,25)$. Supplementation of the calcium salts of by-pass oil improved ADG (36), as well as the efficiency of utilization of nutrients (26). This study was designed to increase the diet energy density by reducing the amount of grain feed (corn) in order to minimize the risk of acidosis in the lamb. The purpose of the study was to examine the feedlot performance, ruminal and blood parameters of Merinos male lambs fed on diet supplemented with RPF during the hot season.

\section{Materials and Methods}

Animal and feed management: The study was performed at the Agriculture, Livestock and Food Research Station of Mehmet Akif Ersoy University. Fourteen Merino male lambs, 6 months of age and at 29.59 of weight, were divided equally into two groups based on their live weights. Accompanying the vaccination program, the study lasted 105 days (from June until August), with the first 15 days constituting the adaptation period. The animals were housed in north-side closed feeding pens with dimensions of $3 \times 3.5 \mathrm{~m}$ to protect them from north-east winds. They were fed every day in their pens at 09.00 and $17.00 \mathrm{~h}$. The lamb concentrate mixture and oat hay in separate feeders and water were provided ad libitum. The ingredient composition of the nutrients in the diets used in the trial is presented in Table 1. In the rumen-protected fat (RPF) group, the amount of grain was decreased by approximately $22.14 \%$ in the concentrate mixture, and the remaining energy was provided by adding $30 \mathrm{~g} / \mathrm{kg}$ of RPF. The diets were formulated to meet the nutrient requirements according to Nutritional Research Council (NRC) (34).
Growth trial: Before morning feeding, the lambs were weighed individually on two consecutive days biweekly to determine their LW. The ADG of each lamb was determined by dividing the live weight gain by the number of days on feed. The concentrate mixture and forage were given separately, and DMI was recorded daily. FCR was calculated as $\mathrm{kg}$ of DMI consumed divided by $\mathrm{kg}$ of LW gained per group.

Chemical composition: The feed samples were dried in a forced ventilation oven at $105^{\circ} \mathrm{C}$ for $24 \mathrm{~h}$. The dried samples were ground to pass through a $1-\mathrm{mm}$ sieve for estimation of the nutritional composition of the feeds as described by the Association of Official Analytical Chemists (AOAC) (2). The feed samples were analyzed based on the methodology of the AOAC for dry matter (DM), ash, ether extract (EE) and crude protein (CP) contents. Neutral detergent fiber (NDF) and acid detergent fiber (ADF) were analyzed according to the method described by Goering and Van Soest (15). Crude fiber (CF) content was analyzed by the procedure of Crampton and Maynard (11). ME content in the feedstuffs and experimental diet was calculated using $\mathrm{EE}, \mathrm{CP}, \mathrm{CF}$ and $\mathrm{CA}$ as determined by chemical analyses $(1,32)$. Digestible dry matter (DDM) was determined by using the ADF content of alfalfa silage. Then, DMI was measured by using the NDF content of alfalfa silage. Relative feed value (RFV) was calculated (34) by using DDM and DMI.

Rumen fermentation characteristics: Rumen fluid samples $(50 \mathrm{~mL})$ were collected by using an oral stomach tube from seven lambs of each group after 6 hours of feeding on d 45 and d 90 of the experimental period. After the rumen fluid samples were taken, the rumen $\mathrm{pH}$ value was immediately determined with a glass electrode $\mathrm{pH}$ meter from the filtrate. The filtrated rumen fluid samples were placed into plastic reagent bottles by acidification with sulfuric acid $(50 \%)$ and frozen at $-20^{\circ} \mathrm{C}$ until being analyzed to determine the ruminal ammonia nitrogen concentrations $\left(\mathrm{NH}_{3}-\mathrm{N}\right)$ with indophenol methods by using a spectrophotometer (21). Afterwards, the samples of ruminal fluids were squeezed through layers of cheesecloth with a mesh size of $250 \mu \mathrm{m}$. Fifteen $\mathrm{mL}$ of the rumen-filtrated samples were preserved into plastic reagent bottles by acidification with $1 \mathrm{~mL}$ of $25 \%(\mathrm{w} / \mathrm{v})$ meta-phosphoric acid and stored at $-20^{\circ} \mathrm{C}$ until being analyzed to determine the molar proportion of VFA concentration [acetate $(\mathrm{C} 2)$, propionate $(\mathrm{C} 3)$, butyrate (C4)] by using gas chromatography (21). Rumen protozoa numbers were identified according to the method of Ogimoto and Imai (29) using a Fuchs-Rosenthal chamber.

Blood samples: Roughly $10 \mathrm{~mL}$ of blood samples was drawn via jugular vein puncture into EDTA tubes and vacutainer blood tubes without an anticoagulant on $\mathrm{d} 45$ and 90 . The blood samples taken into the vacutainer blood tubes without an anticoagulant were centrifuged at 1500 rpm for 15 minutes at room temperature to separate the 
serum and then stored at $-80^{\circ} \mathrm{C}$ until analysis. Serum parameters were determined by an enzymatic and colorimetric procedure using an auto analyzer. The blood in the EDTA-containing tubes was analyzed for hematological parameters by using automated equipment (35).

Statistical analyses: The statistical analyses were conducted with SPSS (Statistical Package for the Social Sciences; Inc., Chicago, IL, USA). The data were analyzed by independent-samples t-test to determine the effects of RPF addition on the feedlot performance, ruminal parameters and blood metabolites in the Merino male lambs. The level of significance was taken as $\mathrm{P}<0.05$ (12).

\section{Results}

The chemical compositions of the feedstuffs and experimental rations are shown in Table 1. The crude protein contents were $17.06 \%$ in the CON group and $16.74 \%$ in the RPF group. The metabolic energies of the CON and RPF groups were found to be 3245.3 and 3231.5 $\mathrm{kcal} / \mathrm{kg}$, respectively. Supplementation of RPF to the lamb diet had no significant effect $(\mathrm{P}>0.05)$ on $\mathrm{LW}$ or ADG during the experiment. As presented in Table 2, RPF supplementation numerically increased $(\mathrm{P}>0.05)$ the overall mean value of ADG by $0.01 \mathrm{~kg} / \mathrm{d}$. The oat hay intake and roughage: concentrated value was lower $(\mathrm{P}<0.05)$ in the RPF group than the CON group during the study except for weeks between 0-2. The concentrated feed intake was similar ( $\mathrm{P}>0.05)$ in both groups (Table 3).
The total dry matter intake (TDMI) was significantly lower $(\mathrm{P}<0.05)$ in the RPF group after sixth week of beginning, while no significant differences $(\mathrm{P}>0.05)$ were observed for FCR (Figure 1). There were no significant differences $(\mathrm{P}>0.05)$ between the groups in terms of the rumen $\mathrm{pH}, \mathrm{NH}_{3}-\mathrm{N}, \mathrm{C} 2, \mathrm{C} 3$ and $\mathrm{C} 4$ concentration on all treatment days (Table 4). The rumen $\mathrm{pH}$ value was numerically decreased $(\mathrm{P}>0.05)$ in the RPF group on $\mathrm{d} 45$, but it increased on d 90. Addition of RPF reduced $(\mathrm{P}>0.05)$ the concentration of $\mathrm{NH}_{3}-\mathrm{N}$ on all treatment days. The $\mathrm{C} 2$ $(\mathrm{mM})$ and $\mathrm{C} 3(\mathrm{mM})$ concentrations were higher $(\mathrm{P}>0.05)$ in the RPF group than the CON group at $\mathrm{d} 45$ but lower at $\mathrm{d}$ 90. There was an increase in the $\mathrm{C} 4$ concentrations in $\mathrm{CON}$ in comparison to that of RPF. The protozoa count was significantly reduced $(\mathrm{P}<0.05)$ by RPF addition on $\mathrm{d}$ 90, but it was unaffected on d 45 (Table 4). The effect of RPF was insignificant $(\mathrm{P}>0.05)$ on the triglyceride, AST, ALT, glucose and HDL-cholesterol levels. The concentrations of LDL-cholesterol were significantly increased $(\mathrm{P}<0.05)$ by adding RPF in comparison to the CON group (Table 5). The HDL-cholesterol concentration was numerically lower $(\mathrm{P}>0.05)$ in the $\mathrm{CON}$ group in comparison to the RPF group. The glucose concentration was insignificantly lower $(\mathrm{P}>0.05)$ in the $\mathrm{CON}$ group in comparison to RPF at d 45 but higher at d 90 (Table 5). For all treatment days, there was no significant effect $(\mathrm{P}>0.05)$ of RPF on the blood hematological parameters except the PLT and PCT values which were higher $(\mathrm{P}<0.05)$ in the RPF group in comparison to the CON group at d 90 (Table 6).

Table 1. Ingredient composition and analyzed content of the nutrients in the diets used in the trial.

\begin{tabular}{|c|c|c|c|c|c|c|}
\hline Ingredients $\left(\mathrm{g} \mathrm{kg}^{-1}\right)$ & CON & RPF & Nutritional content (\%) & & CON & RPF \\
\hline Barley & 100 & 135 & Dry matter & & 90.84 & 93.47 \\
\hline Corn & 600 & 410 & Ash & & 6.00 & 7.64 \\
\hline Wheat bran & 90 & 230 & Organic matter & & 94.00 & 92.36 \\
\hline Sunflower meal & 40 & 45 & Crude fiber & & 4.18 & 6.00 \\
\hline Soybean meal & 144 & 124 & Crude protein & & 17.06 & 16.74 \\
\hline Rumen protected fat & - & 30 & Ether extract & & 2.20 & 3.96 \\
\hline Limestone & 21 & 21 & Neutral detergent fiber & & 16.22 & 20.85 \\
\hline DCP & 2 & 2 & Acid detergent fiber & & 6.68 & 7.99 \\
\hline Salt & 2 & 2 & Hemi-cellulose & & 9.54 & 12.84 \\
\hline \multirow[t]{4}{*}{ Premix ${ }^{1}$} & 1 & 1 & Non-fiber carbohydrate & & 49.36 & 44.28 \\
\hline & & & Nitrogen free extract & & 61.39 & 59.14 \\
\hline & & & $\mathrm{ME}^{*}(\mathrm{kcal} / \mathrm{kg})$ & & 3245.3 & 3231.5 \\
\hline & & & Oat Hay** & & & \\
\hline $\mathrm{ME}_{\mathrm{ADF}}(\mathrm{kcal} / \mathrm{kg})$ & \multicolumn{2}{|c|}{ MENDF $_{\text {(kcal/kg) }}$} & DDM\% & DMI\% & \multicolumn{2}{|c|}{ RFV\% } \\
\hline 2061.7 & \multicolumn{2}{|c|}{2097.9} & 57.35 & 1.86 & \multicolumn{2}{|c|}{83.01} \\
\hline
\end{tabular}

CON: Control group, RPF: Rumen-protected fat group; ${ }^{1}$ Each kilogram of vitamin-mineral mix contains 1,000,000 IU vit A, 200,000 IU Vit D, 1,800 mg vit E, 8,400 mg Zn; *Metabolic energy was calculated by TSI; ** ME ${ }_{\mathrm{ADF}}$, and MENDF were calculated by Alderman (1); DDM: Dry digestible matter, DMI: Dry matter intake; RFV: Relative feed value. [DDM\% $=88.9-(0.779 \times \mathrm{ADF} \%)$ ], $[\mathrm{DMI} \%=120 / \mathrm{NDF} \%)],[\mathrm{RFV}=\mathrm{DDM} \% \times \mathrm{DMI} \% \times 0.775]$. Non-fiber carbohydrate $=[\mathrm{OM} \%-(\mathrm{NDF} \%+\mathrm{CP} \%+\mathrm{EE} \%)]$, Nitrogen free extract $=[\mathrm{DM} \%-(\mathrm{CP} \%+\mathrm{CF} \%+\mathrm{Ash} \%+\mathrm{EE} \%)]$. 
Figure 1. The total dry matter intake (TDMI) (kg/lamb) and feed conversion ratio ( $\mathrm{kg} \mathrm{DM} / \mathrm{kg}$ live weight) of lamb fed on diet supplemented (RPF) or not (CON) with rumen-protected fat.

TDMI: The total dry matter intake

FCR: Feed conversion ratio

CON: Control group

RPF: Rumen-protected fat group

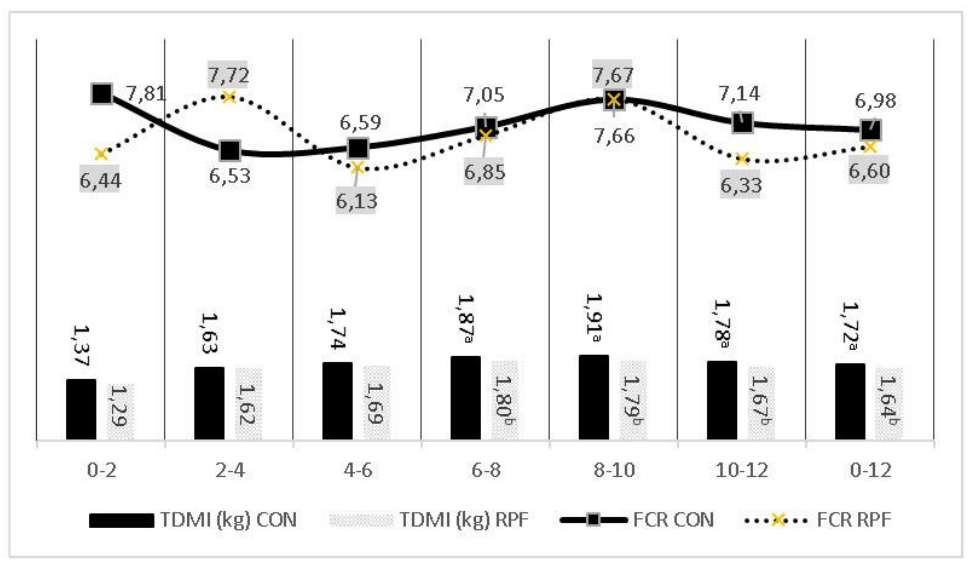

Table 2. The live weight and average daily gain of lamb fed on diet supplemented (RPF) or not (CON) with rumen-protected fat (Mean \pm SEM).

\begin{tabular}{llllllll}
\hline $\begin{array}{l}\text { Items } \\
\text { Weeks }\end{array}$ & CON & Live weight (kg) & \multicolumn{4}{c}{ Average daily gain (kg/d) } \\
RPF & P & Weeks & CON & RPF & P \\
\hline Initial live weight & $29.98 \pm 3.39$ & $29.20 \pm 3.24$ & 0.67 & $0-2$ & $0.20 \pm 0.11$ & $0.30 \pm 0.06$ & 0.06 \\
$2^{\text {nd }}$ & $32.81 \pm 4.17$ & $33.46 \pm 3.90$ & 0.76 & $2-4$ & $0.23 \pm 0.12$ & $0.21 \pm 0.03$ & 0.66 \\
$4^{\text {th }}$ & $36.10 \pm 4.31$ & $36.48 \pm 3.80$ & 0.86 & $4-6$ & $0.29 \pm 0.10$ & $0.28 \pm 0.05$ & 0.89 \\
$6^{\text {th }}$ & $40.20 \pm 3.42$ & $40.49 \pm 4.11$ & 0.89 & $6-8$ & $0.24 \pm 0.12$ & $0.27 \pm 0.04$ & 0.62 \\
$8^{\text {th }}$ & $43.66 \pm 2.76$ & $44.29 \pm 3.78$ & 0.69 & $8-10$ & $0.25 \pm 0.02$ & $0.22 \pm 0.06$ & 0.27 \\
$10^{\text {th }}$ & $47.20 \pm 2.94$ & $47.40 \pm 3.44$ & 0.90 & $10-12$ & $0.26 \pm 0.03$ & $0.25 \pm 0.04$ & 0.87 \\
$12^{\text {th }}$ & $50.75 \pm 3.16$ & $50.91 \pm 3.39$ & 0.93 & $0-12$ & $0.25 \pm 0.02$ & $0.26 \pm 0.01$ & 0.27 \\
\hline
\end{tabular}

CON: Control group, RPF: Rumen-protected fat group.

Table 3. The dry matter intake (g/lamb) and feed conversion ratio (g DM/g live weight) of lamb fed on diet supplemented (RPF) or not $(\mathrm{CON})$ with rumen-protected fat (Mean $\pm \mathrm{SEM})$.

\begin{tabular}{|c|c|c|c|c|}
\hline Week & Groups & Oat hay intake (kg, DM) & $\begin{array}{l}\text { Concentrated Feed intake } \\
(\mathrm{kg}, \mathrm{DM})\end{array}$ & Roughage: Concentrated \\
\hline \multirow{3}{*}{$0-2$} & $\mathrm{CON}$ & $0.38 \pm 0.03$ & $0.98 \pm 0.07$ & $0.39 \pm 0.13$ \\
\hline & RPF & $0.35 \pm 0.04$ & $0.94 \pm 0.04$ & $0.37 \pm 0.12$ \\
\hline & $\mathrm{P}$ & 0.51 & 0.62 & 0.54 \\
\hline \multirow{3}{*}{$2-4$} & $\mathrm{CON}$ & $0.48 \pm 0.05^{\mathrm{a}}$ & $1.15 \pm 0.09$ & $0.41 \pm 0.01^{\mathrm{a}}$ \\
\hline & RPF & $0.40 \pm 0.04^{b}$ & $1.21 \pm 0.14$ & $0.34 \pm 0.02^{\mathrm{b}}$ \\
\hline & $\mathrm{P}$ & 0.02 & 0.35 & 0.01 \\
\hline \multirow{3}{*}{$4-6$} & $\mathrm{CON}$ & $0.50 \pm 0.02^{\mathrm{a}}$ & $1.23 \pm 0.01$ & $0.40 \pm 0.02 \mathrm{a}$ \\
\hline & RPF & $0.45 \pm 0.01^{\mathrm{b}}$ & $1.23 \pm 0.01$ & $0.36 \pm 0.01^{b}$ \\
\hline & $\mathrm{P}$ & 0.04 & 0.79 & 0.049 \\
\hline \multirow{3}{*}{$6-8$} & $\mathrm{CON}$ & $0.61 \pm 0.01^{\mathrm{a}}$ & $1.27 \pm 0.01$ & $0.47 \pm 0.01^{\mathrm{a}}$ \\
\hline & RPF & $0.54 \pm 0.02^{\mathrm{b}}$ & $1.26 \pm 0.01$ & $0.42 \pm 0.02^{b}$ \\
\hline & $\mathrm{P}$ & 0.001 & 0.06 & 0.001 \\
\hline \multirow{3}{*}{$8-10$} & $\mathrm{CON}$ & $0.60 \pm 0.01^{\mathrm{a}}$ & $1.31 \pm 0.01$ & $0.45 \pm 0.01^{\mathrm{a}}$ \\
\hline & $\mathrm{RPF}$ & $0.47 \pm 0.02^{b}$ & $1.31 \pm 0.01$ & $0.36 \pm 0.02^{\mathrm{b}}$ \\
\hline & $\mathrm{P}$ & 0.001 & 0.83 & 0.001 \\
\hline \multirow{3}{*}{$10-12$} & $\mathrm{CON}$ & $0.53 \pm 0.02^{\mathrm{a}}$ & $1.22 \pm 0.01$ & $0.46 \pm 0.01^{\mathrm{a}}$ \\
\hline & RPF & $0.41 \pm 0.01^{b}$ & $1.26 \pm 0.03$ & $0.33 \pm 0.02^{\mathrm{b}}$ \\
\hline & $\mathrm{P}$ & 0.001 & 0.27 & 0.001 \\
\hline \multirow{3}{*}{$0-12$} & $\mathrm{CON}$ & $0.52 \pm 0.01$ & $1.19 \pm 0.01$ & $0.43 \pm 0.04$ \\
\hline & RPF & $0.44 \pm 0.07$ & $1.21 \pm 0.13$ & $0.36 \pm 0.04$ \\
\hline & $\mathrm{P}$ & 0.001 & 0.65 & 0.001 \\
\hline
\end{tabular}

CON: Control group, RPF: Rumen-protected fat group

a,b; Means with different superscripts in the same column are significantly different $(\mathrm{P}<0.05)$. 
Table 4. The rumen fermentation characteristic of lamb fed on diet supplemented (RPF) or not (CON) with rumen-protected fat $($ Mean \pm SEM).

\begin{tabular}{lllllll}
\hline Items & \multicolumn{3}{c}{ Day 45 } & \multicolumn{2}{c}{ Day 90 } \\
& CON & RPF & P & CON & RPF & P \\
\hline $\mathrm{pH}$ value & $7.09 \pm 0.13$ & $7.05 \pm 0.08$ & 0.45 & $6.55 \pm 0.21$ & $6.58 \pm 0.13$ & 0.77 \\
$\mathrm{NH}_{3}-\mathrm{N}(\mathrm{mg} / 100 \mathrm{ml})$ & $4.73 \pm 0.04$ & $4.68 \pm 0.07$ & 0.55 & $4.87 \pm 0.04$ & $4.79 \pm 0.01$ & 0.07 \\
$\mathrm{C} 2(\mathrm{mM})$ & $15.42 \pm 3.48$ & $17.75 \pm 4.17$ & 0.64 & $29.59 \pm 2.08$ & $25.78 \pm 5.4$ & 0.47 \\
$\mathrm{C} 3(\mathrm{mM})$ & $11.66 \pm 4.22$ & $12.40 \pm 5.30$ & 0.91 & $29.66 \pm 2.41$ & $25.75 \pm 3.6$ & 0.25 \\
$\mathrm{C} 4(\mathrm{mM})$ & $4.42 \pm 1.59$ & $3.61 \pm 0.55$ & 0.63 & $11.19 \pm 2.52$ & $10.44 \pm 1.36$ & 0.77 \\
Protozoa count & $172 \pm 14.12$ & $156 \pm 16.31$ & 0.71 & $170.35 \pm 16.35^{\mathrm{a}}$ & $91.78 \pm 16.91^{\mathrm{b}}$ & 0.005 \\
\hline (10 cell/mL) & & & & & &
\end{tabular}

CON: Control group, RPF: Rumen-protected fat group

a,b; Means with different superscripts in the same row are significantly different $(\mathrm{P}<0.05)$.

Table 5. The blood biochemical parameters of lamb fed on diet supplemented (RPF) or not (CON) with rumen-protected fat $(\mathrm{Mean} \pm \mathrm{SEM})$.

\begin{tabular}{lllllll}
\hline Items & \multicolumn{3}{c}{ Day 45 } & \multicolumn{2}{c}{ Day 90 } \\
& CON & RPF & P & CON & RPF & P \\
\hline Cholesterol (mg/dl) & $56.87 \pm 3.50^{\mathrm{a}}$ & $68.00 \pm 3.85^{\mathrm{b}}$ & 0.04 & $60.85 \pm 5.42$ & $68.28 \pm 3.92$ & 0.28 \\
Triglyceride (mg/dl) & $30.00 \pm 1.37$ & $35.57 \pm 3.53$ & 0.18 & $24.42 \pm 3.77$ & $22.85 \pm 2.24$ & 0.73 \\
AST (U/L) & $117.11 \pm 6.86$ & $111.1 \pm 5.76$ & 0.51 & $119.11 \pm 10.04$ & $111.82 \pm 3.74$ & 0.51 \\
ALT (U/L) & $21.15 \pm 1.39$ & $17.28 \pm 1.99$ & 0.13 & $19.42 \pm 1.71$ & $19.14 \pm 1.96$ & 0.91 \\
Glucose (mg/dl) & $83.72 \pm 6.28$ & $99.72 \pm 6.58$ & 0.10 & $79.57 \pm 2.83$ & $75.42 \pm 1.78$ & 0.24 \\
HDL (mg/dl) & $31.28 \pm 1.88$ & $32.71 \pm 1.75$ & 0.59 & $33.57 \pm 2.33$ & $36.14 \pm 2.32$ & 0.45 \\
LDL (mg/dl) & $15.57 \pm 0.57^{\mathrm{a}}$ & $18.28 \pm 1.16^{\mathrm{b}}$ & 0.04 & $19.57 \pm 0.99^{\mathrm{a}}$ & $23.28 \pm 0.89^{\mathrm{b}}$ & 0.02 \\
\hline CON: Com
\end{tabular}

CON: Control group, RPF: Rumen-protected fat group, AST: Aspartate aminotransferase, ALT: Alanine aminotransferase, HDL: Highdensity lipoprotein, LDL: Low-density lipoprotein

a,b; Means with different superscripts in the same row are significantly different $(\mathrm{P}<0.05)$.

Table 6. The blood hematological parameters of lamb fed on diet supplemented (RPF) or not (CON) with rumen-protected fat $(\mathrm{Mean} \pm \mathrm{SEM})$.

\begin{tabular}{|c|c|c|c|c|c|c|}
\hline \multirow{2}{*}{ Items } & \multicolumn{3}{|c|}{ Day 45} & \multicolumn{3}{|c|}{ Day 90} \\
\hline & CON & RPF & $\mathbf{P}$ & CON & RPF & $\mathbf{P}$ \\
\hline $\mathrm{WBC}\left(\mathrm{x} 10^{3} / \mu \mathrm{L}\right)$ & $8.92 \pm 1.28$ & $11.17 \pm 1.21$ & 0.23 & $10.60 \pm 1.75$ & $12.63 \pm 1.73$ & 0.43 \\
\hline $\operatorname{LYM}\left(x 10^{3} / \mu \mathrm{L}\right)$ & $5.09 \pm 1.20$ & $4.69 \pm 0.55$ & 0.76 & $5.37 \pm 1.38$ & $4.84 \pm 0.51$ & 0.72 \\
\hline $\operatorname{MID}\left(x 10^{3} / \mu \mathrm{L}\right)$ & $0.04 \pm 0.01$ & $0.05 \pm 0.01$ & 0.25 & $0.05 \pm 0.01$ & $0.06 \pm 0.01$ & 0.38 \\
\hline GRA $\left(x 10^{3} / \mu \mathrm{L}\right)$ & $3.78 \pm 0.70$ & $6.42 \pm 0.79$ & 0.03 & $5.18 \pm 0.63$ & $7.32 \pm 1.02$ & 0.11 \\
\hline $\mathrm{RBC}\left(\mathrm{x} 10^{3} / \mu \mathrm{L}\right)$ & $9.91 \pm 0.61$ & $10.22 \pm 0.33$ & 0.66 & $10.71 \pm 0.67$ & $11.22 \pm 0.38$ & 0.53 \\
\hline $\mathrm{HGB}(\mathrm{g} / \mathrm{dL})$ & $11.14 \pm 0.69$ & $10.54 \pm 0.43$ & 0.47 & $11.60 \pm 0.41$ & $11.10 \pm 0.51$ & 0.48 \\
\hline $\operatorname{HCT}(\%)$ & $30.53 \pm 1.58$ & $29.65 \pm 0.82$ & 0.63 & $33.81 \pm 1.26$ & $32.36 \pm 1.68$ & 0.51 \\
\hline $\mathrm{MCV}, \mathrm{fL}$ & $30.14 \pm 0.70$ & $30.00 \pm 0.95$ & 0.90 & $30.40 \pm 0.60$ & $30.20 \pm 1.15$ & 0.88 \\
\hline $\mathrm{MCH}, \mathrm{pg}$ & $10.62 \pm 0.25$ & $25.20 \pm 0.35$ & 0.32 & $10.44 \pm 0.19$ & $10.34 \pm 0.32$ & 0.79 \\
\hline $\mathrm{MCHC}(\mathrm{g} / \mathrm{dL})$ & $35.45 \pm 0.53$ & $36.41 \pm 0.63$ & 0.27 & $34.42 \pm 0.52$ & $34.30 \pm 0.85$ & 0.90 \\
\hline RDW (\%) & $25.95 \pm 0.48$ & $25.94 \pm 0.78$ & 0.98 & $24.40 \pm 0.47$ & $26.04 \pm 0.87$ & 0.13 \\
\hline $\operatorname{PLT}\left(x 10^{3} / \mu \mathrm{L}\right)$ & $655 \pm 96.7$ & $604 \pm 33.5$ & 0.63 & $525 \pm 86.5^{\mathrm{b}}$ & $755 \pm 56.0^{\mathrm{a}}$ & 0.04 \\
\hline РCT & $0.39 \pm 0.05$ & $0.37 \pm 0.01$ & 0.71 & $0.31 \pm 0.04 \mathrm{a}$ & $0.46 \pm 0.04 \mathrm{a}$ & 0.05 \\
\hline MPV,fL & $5.95 \pm 0.06$ & $6.15 \pm 0.15$ & 0.23 & $6.14 \pm 0.18$ & $6.10 \pm 0.15$ & 0.87 \\
\hline
\end{tabular}

CON: Control group, RPF: Rumen-protected fat group, WBC: White blood cell, LYM: Lymphocyte, MID: Monocyte, GRA: Granulocyte, RBC: Red blood cell, HGB: Hemoglobin, HCT: Hematocrit, MCV: Mean corpuscular volume, MCH: Mean corpuscular hemoglobin, MCHC: Mean corpuscular hemoglobin concentration, RDWc: Red blood cell distribution Width, PLT: Platelet, PCT: Platelet crit, MPV: Mean Platelet Volume ${ }^{\mathrm{a}, \mathrm{b}}$; Means with different superscripts in the same row are significantly different $(\mathrm{P}<0.05)$. 


\section{Discussion and Conclusion}

The LW of lambs in the CON group and RPFsupplemented group were 50.75 and 50.91 at the end of the experiment, respectively. The increase in the ADG by $0.01 \mathrm{~kg} /$ day in the RPF-supplemented diet may be associated with the intake of concentrated feed, which consists of $1.21 \mathrm{~kg}$ of DM. Supplementation of RPF to the lamb diet had no significant effect on ADG during the experiment. The results of this study were in accordance with Manso et al. (23), who showed insignificant increases in ADG and LW. Likewise, Bhatt et al. (6) reported that final live weight and ADG were significantly higher in the Ca-soap group in comparison to the control. Oat hay intake was lower (approximately 15.39\%) and concentrated feed intake was higher (1.61\%) observed in the RPF group, which suggested that increased energy density of the ration limits the thermic effects of feeding. The feed intake could be more closely associated with heat stress. Heat increment is increased by forage intake more than concentrate, and it is generally thought to be closely related to the metabolism of acetate (14). As expected, the decrease in the acetate by $13.18 \%$ in the RPFsupplemented diet may be associated with the heat increment. Conversely, neither fat nor concentrate addition changed DMI when cows were exposed to hot weather $(7,24)$. Bhatt et al. (6) stated that decreased hay intake might be attributed to an increase in the energy density of diet due to the chemo-static regulation of voluntary intake. They (6) also reported decreased roughage intake and increased concentrate intake with addition of Ca-soap fat in the diets of Malpura lambs. Addition of RPF did not affect the ruminal $\mathrm{pH}$. The findings of this study were in agreement with results of previous studies conducted on cattle (20) and lambs (6). A significant increase in ruminal $\mathrm{pH}$ with $\mathrm{RPF}$ supplementation could be mainly associated with the maintenance of better rumen environment (7). The greater ruminal $\mathrm{pH}$ in RPF-fed lambs compared to control-fed lambs might provide greater production of buffering agents (i.e., saliva) resulting from an increase in rumination time during the hot season (24). A partial degradation of RPF might likely have contributed to the buffer capacity of ruminal $\mathrm{pH}$, which prevents decline in ruminal $\mathrm{pH}$ (7). Bhatt et al. (6), observed a higher ruminal $\mathrm{pH}$ upon addition of RPF to the diets of lambs. The concentration of $\mathrm{NH}_{3}-\mathrm{N}$ was lower $(\mathrm{P}>0.05)$ in the $\mathrm{RPF}$ group than the $\mathrm{CON}$ group at $\mathrm{d} 45$ and $\mathrm{d} 90$. In comparison to control group, the $\mathrm{NH}_{3}-\mathrm{N}$ concentration in the ruminal fluid of the lambs fed with RPF in this study was found to be about $4.79 \mathrm{mmol} / \mathrm{L}$ at $\mathrm{d} 90$. The decrease in the $\mathrm{NH}_{3}-\mathrm{N}$ concentration in the ruminal fluid could be explained by the increase in the amino acid flow from the stomach to the intestinal tract due to utilization and absorption, which was associated with defaunation of protozoal counts (19).
A low protozoal count was found in this study, further supported this condition. This may be explained by the greater proliferation of bacteria (4). The findings of this study proved that RPF supplementation numerically decreased the molar proportion of $\mathrm{C} 2, \mathrm{C} 3$ and $\mathrm{C} 4$, these results agreed with the data published by Bhatt et al. (6). To some extent, this explains that the increase in the molar proportion of $\mathrm{C} 3$ in the $\mathrm{CON}$ group was associated with the lambs fed the high-cereal diet (3) and thus increased the concentration of glucose due to the gluconeogenic effect. In this study, the increase in the molar concentration of $\mathrm{C} 2$ in the $\mathrm{CON}$ group in comparison to the RPF group was associated with an increase in the oat hay intake. This was an inconsistent with the results of Kang et al. (20), who revealed that RPF increased C2 and C3. Bettero et al. (5) achieved a similar acetate concentration in sheep by adding rumen protected fat to their diets. Similar to this study, Bhatt et al. (6) also showed a lower protozoon count with RPF supplementation in lamb diets. This could be due to the breakdown of symbiotic rumen protozoa-methanogenic bacteria interaction and subsequent interspecies $\mathrm{H}_{2}$ transfer resulting in limitation of $\mathrm{H}_{2}$ production during fermentation, which was associated with the higher $\mathrm{pH}$ of the ruminal fluid $(6,19)$. At $d 45$ of the experiment, the lambs fed the RPF diet had higher cholesterol concentrations than those fed the control diet $(\mathrm{P}<0.05)$. Similar findings were emphasized by Bhatt et al. (6), who also showed increased cholesterol concentrations using RPF in the basal diets of lambs. The same authors stated that cholesterol concentrations might be increased due to stimulation in its synthesis by supplementation of RPF. Similar observations of an increase in cholesterol concentrations through feeding of RPF were also reported by Tyagi et al. (33) and Wadhwa et al. (36). The lambs fed RPF had insignificantly higher glucose concentrations, as well as lower concentrations of AST and ALT than those in the control group at $\mathrm{d} 45$. In growing diets, RPF may be used as a substitute for grain feeds to ensure that the energy density in lamb rations does not cause adverse impacts on the glucose concentration (18). Tyagi et al. (33) also reported no significant impact of RPF on glucose levels. The hematocrit level slightly increased during the experiment. Vieira et al. (35) stated that a low pH causes splenic contraction because of the action of epinephrine resulting in increased hematocrit.

In conclusion, a review of the literature showed that the statistically significant or insignificant differences were mostly due to individual differences in the animals such as live weight, sex and age of the animal or forage type and ingredients of the concentrate mixture lamb feed. The current results of the study indicated that dietary supplementation of RPF at $30 \mathrm{~g} / \mathrm{kg}$ slightly increased the LW and ADG. In comparison to CON, addition of RPF 
did not affect the ruminal $\mathrm{pH}$ value, $\mathrm{NH}_{3}-\mathrm{N}$ concentration, molar proportion of $\mathrm{C} 2, \mathrm{C} 3$ and $\mathrm{C} 4$, whereas it significantly reduced the forage intake and the rumen protozoa numbers. RPF supplementation affected the serum blood parameters such as cholesterol and LDL cholesterol. It is concluded that RPF is important especially for forage intake. Therefore, further research is required to understand the influence of different rates of RPF on male lamb nutrition.

\section{Financial Support}

This work was supported by a grant from the Scientific Research Projects Coordination Unit of Mehmet Akif Ersoy University (Project number: 0343-NAP-16).

\section{Ethical Statement}

All procedures were warranted by the Ethics Committee for Animal Use of the Mehmet Akif Ersoy University (Protocol number: 26.05.2015/132).

\section{Conflict of Interest}

We certify that there is no conflict of interest with any financial organization regarding the material discussed in the manuscript

\section{References}

1. Alderman G (1985): Prediction of the energy value compound feeds. 3-52. In: W Haresign (Ed), Recent Advances in Animal Nutrition. Butterworth-Heinemann Press, London.

2. AOAC (1990): Association of Official Analytical Chemists. 69-88. In: K Helrich (Ed), Official Methods of Analysis. USA

3. Beever DE (2000): Forage evaluation for efficient ruminant livestock production. 15-42. In: DI Givens, E Owen, RFE, Axford (Eds), Forage Evaluation in Ruminant. CABI Publishing Nutrition, Oxon, United Kingdom.

4. Behan AA, Loh TC, Fakurazi S, et al (2019): Effects of supplementation of rumen protected fats on rumen ecology and digestibility of nutrients in sheep. Animals, 9, 2-18.

5. Bettero VP, Valle TAD, Barletta RV, et al (2017): Use of protected fat sources to reduce fatty acid biohydrogenation and improve abomasal flow in dry dairy cows. Anim Feed Sci Technol, 224, 30-38.

6. Bhatt RS, Karim SA, Sahoo A, et al (2013): Growth performance of lambs fed diet supplemented with rice bran oil as such or as calcium soap. Asian-Australas J Anim Sci, 26, 812-819.

7. Bhatt RS, Sahoo A, Karim SA, et al (2016): Effects of Saccharomyces cerevisiae and rumen bypass-fat supplementation on growth, nutrient utilization, rumen fermentation and carcass traits of lambs. Anim Prod Sci, 58, 530-538.

8. Bhatt RS, Soren NM, Tripathi MK, et al (2011): Effects of different levels of coconut oil supplementation on performance, digestibility, rumen fermentation and carcass traits of Malpura lambs. Anim Feed Sci Technol, 164, 29-37.
9. Borton RJ, Loerch SC, McClure KE, et al (2005): Comparison of characteristics of lambs fed concentrate or grazed on ryegrass to traditional or heavy slaughter weights. I. Production, carcass, and organoleptic characteristics. J Anim Sci, 83, 679-685.

10. Brown MS, Krehbiel CR, Galyean ML, et al (2000): Evaluation of models of acute and subacute acidosis on dry matter intake, ruminal fermentation, blood chemistry, and endocrine profiles of beef steers. J Anim Sci, 78, 31553168.

11. Crampton EW, Maynard LA (1938): The relation of cellulose and lignin content to nutritive value of animal feeds. J Nutr, 15, 383-395.

12. Dawson B, Trapp RG (2001): Basic and clinical biostatistics. 3rd ed., Lange Medical Books/ McGraw-Hill Medical Publishing Division, New York, USA. 89, 131153.

13. Diaz TG, Branco AF, Jacovaci FA, et al (2018): Inclusion of live yeast and mannan-oligosaccharides in high grainbased diets for sheep: Ruminal parameters, inflammatory response and rumen morphology. PLoS ONE, 13, 1-12.

14. Gilhossein M, Mahjoubi E, Zahmatkesh D, et al (2017): Exposure to sunlight results in lower concentrate intake during the hot hours of day in a cafeteria feeding of chopped alfalfa hay and concentrate in Afshari lambs. Small Ruminant Res, 157, 8-13.

15. Goering HK, Van Soest PJ (1970). Forage Fibre Analysis, Agric Handbook No, 379. Washington, DC (Agricultural Research Service) US, Department Agriculture.

16. Gümüş H, Şehu A (2016): Effect of yeast culture supplementation to beef rations on feedlot performance, some rumen and blood parameters. Ankara Univ Vet Fak Derg, 63, 39-46.

17. Haddad SG, Younis HM (2014): The effect of adding ruminally protected fat in fattening diets on nutrient intake, digestibility and growth performance of Awassi lambs. Anim Feed Sci Technol, 113, 61-69.

18. Hammon HM, Metges CC, Junghans P, et al (2007): Metabolic changes and net portal flux in dairy cows fed a ration containing rumen-protected fat as compared to a control diet. J Dairy Sci, 91, 208-217.

19. Ivan M, Mir PS, Koenig KM, et al (2001): Effects of dietary sunflower seed oil on rumen protozoa population and tissue concentration of conjugated linoleic acid in sheep. Small Ruminant Res, 41, 215-227.

20. Kang HJ, Piao MY, Park SJ, et al (2019): Effects of heat stress and rumen-protected fat supplementation on growth performance, rumen characteristics, and blood parameters in growing Korean cattle steers. Asian-Australas J Anim Sci, 32, 826-833.

21. Liu HW, Xiong BH, Li K, et al (2015): Effects of suaeda glauca crushed seed on rumen microbial populations, ruminal fermentation, methane emission, and growth performance in Ujumqin lambs. Anim Feed Sci Technol, 210, 104-113.

22. Mahmood AK, Khan MS, Khan MA, et al (2013): Lactic acidosis in goats: prevalence, intra-ruminal and haematological investigations. J Anim Plant Sci, 23, 1527 1531.

23. Manso T, Castro T, Mantecon AR, et al (2006): Effects of palm oil and calcium soaps of palm oil fatty acids in 
fattening diets on digestibility, performance and chemical body composition of lambs. Anim Feed Sci Technol, 127, 175-186.

24. Moallem U, Altmark G, Lehrer H, et al (2010): Performance of high-yielding dairy cows supplemented with fat or concentrate under hot and humid climates. $\mathrm{J}$ Dairy Sci, 93, 3192-3202.

25. Naik PK (2013): Bypass fat in dairy ration. Anim Nutr Feed Technol, 13, 147-163.

26. Naik, PK, Saijpaul S, Neelam R (2009): Effect of ruminally protected fat on in vitro fermentation and apparent nutrient digestibility in buffaloes (Bubalus bubalis). Anim Feed Sci Technol, 153, 68-76.

27. Nocek JE (1997): Bovine acidosis: Implications on laminitis. J Dairy Sci, 80, 1005-1028.

28. NRC (2000): National Research Council, Nutrient Requirements of Small Ruminants. National Academy Press, Washington, DC, USA.

29. Ogimoto K, Imai S (1981): Atlas of Rumen Microbiology. Societies Press, Tokyo.

30. Seabrook JL, Peel RK, Engle TE (2011): The effects of replacing dietary carbohydrate with calcium salts of fatty acids on finishing lamb feedlot performance, blood metabolites, muscle fatty acid composition, and carcass characteristics. Small Ruminant Res, 95, 97-103.
31. Shankhpal S, Parnerkar S, Bhanderi BM (2016): The effect of feeding bypass fat and yeast (Saccharomyces cerevisiae) supplemented total mixed ration on feed intake, digestibility, growth performance and feed conversion efficiency in weaner Surti kids. Livest Res International, 4, 11-17.

32. TSE (1991): Turkish Standards Institute, Animal feeds determination of metabolizable energy (Chemical Method), 1-3.

33. Tyagi N, Thakur SS, Shelke SK (2010): Effect of feeding bypass fat supplement on milk yield, its composition and nutrient utilization in crossbred cows. Indian J Anim Res, 26, 1-8.

34. Van Dyke NJ, Anderson PM (2000): Interpreting a forage analysis. 890. Alabama Cooperative Extension. USA.

35. Vieira AC, Camara AC, Mendonça CL, et al (2012): Hematological and biochemical profile of sheep supplemented with salinomycin and submitted to experimental lactic ruminal acidosis. J Ci Anim Bras, 13, 259-271.

36. Wadhwa M, Grewal RS, Bakshi MPS, et al (2012): Effect of supplementing bypass fat on the performance of high yielding crossbred cows. Indian J Anim Sci, 82, 200-203.

37. Xu Y, Ding Z (2011): Physiological, biochemical and histopathological effects of fermentative acidosis in ruminant production: a minimal. Span J Agric Res, 9, 414422. 